\title{
Development of Sustainable Beef Dendeng Agro industry Business Scale in Aceh Province with SWOT Analysis Case Study: Beef Dendeng Aceh of PT. Gunung Seulawah
}

\author{
Sitti Zubaidah ${ }^{1}$, Suryani ${ }^{1}$, Zaenal Fanani ${ }^{2}$, Budi Hartono ${ }^{2}$, Lilik Eka Radiati ${ }^{2}$, \\ Dimas Pratidina Puriastuti Hadiani ${ }^{3}$ and Feby Milanie ${ }^{4}$ \\ \{dacha.aceh@gmail.com\} \\ ${ }^{1}$ Department of Livestock, Universitas Almuslim, Bireuen, Indonesia \\ ${ }^{2}$ Faculty of Animal Husbandry, Universitas Brawijaya, Malang, Indonesia \\ ${ }^{3}$ Department of Livestock, Universitas Kanjuruhan, Malang, Indonesia \\ ${ }^{4}$ Department of Management, Universitas Pembangunan Panca Budi, Medan, Indonesia
}

\begin{abstract}
The development of sustainable agro industrial scale beef dendeng aceh (BDA) in Banda Aceh City has never been done as one of the regional economic improvement. The purpose of this study is how the strategy of developing the business of BDA in Banda Aceh City, become a new scientific contribution in the development of science in the field of agro industry of sustainable livestock and become a new concept for the development of other local agro industry. This research has been conducted for a year through analysis of SWOT on agro-industry of small-scale BDA that has been established over 25 years. The result of this research that in ABDA-GS have internal factor strength is $>2.50$ while the weakness $<2.50$ meanwhile treats is also >2.50. Therefore, the ABDA-GS business scale development strategy is an internal factor that needs to be improved, strengthened, and retained are product and capital, and promotion, service, corporate finance, innovation, and business risk (weakness), while external factors are necessary to enhance, utilize or cooperate, consumers, technology, the involvement of the Aceh Government, current economic conditions, socio-cultural activities and traders (opportunities) and market share, the same business competitors inside and outside areas as well as security.
\end{abstract}

Keywords: Livestock Agro Industry, Beef Dendeng, Internal Factor, External Factor, Sustainable

\section{INTRODUCTION}

PT Gunung Seulawah Dendeng Aceh is a small-scale industries that move in the field of meat processing since 1982 until now (above 25 years) to obtain permission from The Ministry of Industry No. 157/117/IX/ 87 with the code MD 9881521. The location of the 
product sales business this beef dendeng in Jl Tgk. Chik di Tiro, Simpang Surabaya No. 148150 Banda Aceh.

Beef dendeng business is growing rapidly with high product demand level, so that changed to a limited Liability Company (PT. Gunung Seulawah) with Notary deed No. 10/Not/PSA/V/1999 date 20 May 1999. After post-Tsunami 2004, PT Gunung Seulawah managed directly by the family of $\mathrm{Mr} \mathrm{H}$. Lukman Hakim, and have some employees in the field of production, packaging, marketing and finance. Pt Gunung Seulawah besides producing beef dendeng, also produce dendeng deer and cracker cow skin. The production of beef dendeng produced with the size of the 250 grams price IDR. 65,000,- and 500 grams price IDR.130,000,.

According to the report KPjU Aceh Province (2012) that the number of business players beef dendeng aceh in the city of Banda Aceh which has been registered in Disperindakop SMB of the city of Banda Aceh consists of 9 units of business namely Dendeng Seulawah and Dendeng Blangrakal (including small scale), Dendeng Aceh, rencong Aceh, Dendeng Bungoeng Jaroe, Dendeng Crown, Dendeng Pinto Aceh, Dendeng Putro Seulawah, and Dendeng Seulawah Agam (including the scale of micro business).

To do further research relateds to strategy of business scale beef dendeng sustainable development in aceh.

\section{METHOD}

\subsection{Place and Time}

Determination of the research done by research areas deliberately (purposive sampling) with business time above 25 years, with the research from February 2016 - February 2017.

\subsection{Measurement}

The measurement in this research is used by the survey explorative and descriptive. Method of explorative aims to get a description of the phenomenon is the temporary and permanent about agro-industry Beef Dendeng Aceh (ABDA), while the description of the method aims to get more information about the development of ABDA Business in a specific period of time with how to describe the research object at the current situation based on the facts as the data of quantitative collection from qualitative, be clarified in, and analyzed while the description of the method aims to get more information in a specific period of time with how to describe the research object at the current situation based on the facts as the quantitative data collection, then arranged, be clarified in, analyzed and interpreted.

\subsection{Population and Sample}

The population in this research is a number of the population of infinite wisdom and infinite [1], while the sample is part of the number and characteristics which owned by the population.

The number of large populations (sampling ) in this study because of limited funding research time and energy. Based on some opinions Dillon and Hardaker [2] then sampling in research can be done by considering the adequacy of the framework samples, the aim of the research, the availability of data and resources required, while the priority of the 
recommendations of the innovative model of agro industry development beef dendeng aceh sustainable development through the method of Strength, Weakness, Opportunities, Treats Analysis (SWOT Analysis) on business players ABDA [3].

Sampling in research is on the SWOT Method sampling on business players in the sampling Judgmental sampling based on the scale of business namely the scale of small businesses and have experience (experience) above 25 years namely Beef Dendeng Gunung Seulawah.

\subsection{Data Collection Method}

The data that used in the data obtained directly from the questioner were quantitative and qualitative research that has in advance while the interview used to get more information with the consumer, business players and expertise related to.

Secondary data is data that is not directly and acquired from business practitioners, Dinas or related institutions, publication of institutions that are relevant, Laws Government Regulation, the Decree of the Minister of Agriculture, RPJM Ministry of Agriculture, Local Government Regulations Aceh, RPJM Local Government Of Aceh, Strategic SKPA, Data BPS and other data source.

Equations in this research are:

Weight Value (A) x Average Value (B) = Score Weight (C)

Strengths $(\mathrm{S})+$ Opportunities $(\mathrm{O})=$ SO Strategy

Weakness $(\mathrm{W})+$ Opportunities $(\mathrm{O})=$ WO Strategy

Strengths $(\mathrm{S})+$ Treats $(\mathrm{T})=$ ST Strategy

Weakness $(\mathrm{W})+$ Treats $(\mathrm{T})=$ WT Strategy

\section{Results}

\subsection{Analysis of Business Practitioners with SWOT Method}

The results of The Analysis Variables The Internal Factors - Strength ABDA-GS at the Table 1 and Table 2. provides information that the highest internal factor is the product quality, due to also use frozen beef imports by $98 \%$ and 2 percent using the remaining local beef from the proceeds from the sale of local beef to consumers fresh meat, while the lowest factor is labour, this is due to indiscipline employees in working in the industry.

Overall the total value of the average The Internal Factors on the strength is above the value is still below the 2.5 namely listing 2.33. The The Internal Factors on the strength of which has a value above 2.5 is product quality and capital. This is relevant with (Chen, 2009) that facing tight competition business need to apply as a capital expenditure of ABDA platform GS in the improvement of the quality of the products. 
Table 1. The Average value of the variables The Internal Factors on the ABDA GS

\begin{tabular}{lc}
\hline The Internal Factors & The average value \\
\hline Strenghts - S & 3.60 \\
Product Quality & 1.80 \\
Product Prices & 2.40 \\
Product Access & 1.00 \\
Employment & 3.00 \\
Capital & \\
Weakness - W & 2.00 \\
Product durability & 1.20 \\
Business Risk & 1.60 \\
Product Innovation & 2.20 \\
Product Promotion & 2.20 \\
Employee Services & 1.67 \\
Corporate Finance & \\
\hline
\end{tabular}

Table 2. The Average value of the variables The Internal Factors on the ABDA GS

\begin{tabular}{lc}
\hline The External Factors & The average value \\
\hline Opportunities - O & 3.67 \\
Partner Relationship & 3.67 \\
Customer Relationship & 3.67 \\
Technology & 3.33 \\
Economic Conditions & 2.00 \\
The availability of raw & \\
material & 2.33 \\
The raw material & \\
supply & 3.67 \\
The involvement of & \\
local government & 3.33 \\
Social and Culture & 3.33 \\
Traders Broker & \\
Treaths - T & 4.00 \\
The market share & 2.33 \\
Climate Change & 3.33 \\
Security & 2.00 \\
Politic & 3.33 \\
The competition & \\
outside the area & 3.33 \\
The same business & \\
Competitors & \\
Prices of raw materials & \\
\hline
\end{tabular}

\subsection{The Matrix Strength - Weakness - Opportunity -Threat (SWOT)}

The results from the formulation of the alternative strategy of matching the value of IFAS EFAS Variable The Internal Factors and External Factors on the ABDA -GS Variable in Table 3. 
Table 3. The Matrix IFAS and EFAS ABD-GS Aceh

\begin{tabular}{ccc}
\hline $\begin{array}{c}\text { The Main The } \\
\text { Internal Factors } \\
(\mathrm{S} \text { and } \mathrm{W})\end{array}$ & $\begin{array}{c}\text { The Main } \\
\text { External Factors } \\
(\mathrm{O} \text { and } \mathrm{T})\end{array}$ & $\begin{array}{c}\text { The strategy } \\
\text { that produced }\end{array}$ \\
\hline $\mathrm{S}=2.70$ & $\mathrm{O}=3.33$ & $\mathrm{SO}=-0.63$ \\
$\mathrm{~W}=1.86$ & $\mathrm{O}=3.33$ & $\mathrm{WO}=-1.47$ \\
$\mathrm{~S}=2.70$ & $\mathrm{~T}=3.05$ & $\mathrm{ST}=-0.35$ \\
$\mathrm{~W}=1.86$ & $\mathrm{~T}=3.05$ & $\mathrm{WT}=-1.19$ \\
\hline
\end{tabular}

Table 3 provides information that the result of the value of the factor opportunities $(\mathrm{O})$ on the ABD GS greater namely 3.33 and threat value $(\mathrm{T})$ is 3.05 while the value of The Strengths namely 2.70 , and the value of the weakness namely 1.88 , so that the alternative strategy of external and The Internal Factors on the ABD GS is as follows.

\subsection{QSPM}

The best strategy on ABDA - GS from the results of the input analysis Stage 1 (first) and Stage 2 (two) from the Total Strategic Quantitative (QSPM), the ABDA GS is the overall number of Total Attraction (Sum Total Attractive Score of STAS) on the First strategy is the ABD GS (5.82), with the key factors that have the value of the attraction: 1. Very Interesting (U.S. value 4) consists of The Internal Factors namely product quality, product prices, access product, capital, product innovation and financial companies, and external factors are partners relationship, consumers relationship, raw materials available, supplying raw materials, security, competitor outside area, the business competitors, raw material cost and security.

\section{DISCUSSION}

On the weakness of (W) ABDA GS Weakness - The GS has the highest value on the promotion of our products and services employees, this is due to the ABDA GS actively involved in the exhibition held by the government in Aceh or outside aceh i.e. Local Government brought the ABD-GS products to the national level exhibition held by other provinces. The factor of weakness is the lowest is innovation product, because the taste of beef dendeng produced still is not changed the foxes. This is due to the owner of ABDA GS itself is preparing ingredients and then submitted to the work force. Overall the internal Factors of ABD GS at the weakness still under 2.5 namely 86.62, and none of the The Internal Factors on the weakness that has a value above 2.5 .

Therefore, The Internal Factors ABDA-GS shows that the power that is owned by the ABDA-GS also need to be increased and maintained so that capable to overcome the weakness that owned such as the improvement of the quality of that according to the consumers, capital improvement efforts through other parties such as banking, ease consumers get the products with the strategic market, product prices also must be in accordance with the money paid by consumers and improvement of labour skills training.

Relevant with Kusdiarni [4] stated that the increase in the The Internal Factors such as product characteristic and performance ABD GS performance has a significant impact on strengthening the business players ABDA-GS, can reduce the weakness of the ABDA GS on power factor hold product, business risk, product innovation, product promotion, employees and financial services companies. 
Ismail [5] stated that institutions that good is the main key to the success of agro industry which is capable of raising the competitive advantages and Zhou [6] also added that the quality of information about the products produced related to relevance, adequacy, accuracy, and time information, because the information of quality will improve capital between the buyer and seller with 2 reasons namely 1) allows customers to get a useful information and 2) help business players in developing the understanding of better products [7].

The results of the analysis of variables External Factors Opportunities (Opportunities- O) ABDA-GS Aceh can be seen in the Table 2. that the highest value Internal factor in the opportunity is the relationship with business partners and customers, technology and the involvement of local government in it, this is because the product sales done together as partners in the souvenir shop, supermarket, hotel, the airport and the house eat, relationships with customers is very good due to the creation of the first beef dendeng products is the ABDA GS, so that the products beef dendeng aceh ABD-GS always recommended by the local government involved for the product exhibition was held at the centre or the Province of the other districts and also get the allowance of funds in the construction of the building drying beef dendeng from its fiscal regional funds and the ABD GS has been using technology tools such as the engine grinder herbs, machine Slicer meat, freezer, and sillier.

Overall the total value of the average external factors is above the value of the average 2.5 namely 3.2 consists of factors relationship with partners, customer relationships, technology used in the production of the involvement of the government in the development of business activities of social and cultural cooperation with merchants intermediary, and supplying raw materials from Medan.

Analysis of the external factors on the threat (T) ABDA-GS Treats--GS at the table 2. provides information that the highest value on the Market Share due to the production of which is produced in large number with the use of fresh beef $1310.95 \mathrm{~kg}$ a month, this is due to the extent of the location of the spread of the product to in the market as in the city of Banda Aceh, Aceh Besar, Bireuen district, city of Lhokseumawe, City Langsa, Meulaboh, District, and Medan. While the lowest value on political factors and raw materials, this is due to the heat of the national political in temperature can make the economy cycle difficult player of business and raw materials such as cattle with limited local population and also a high price due to the request of the local community to the local beef high. Overall the total value of the average above 2.5 namely 2.9 consists of market factors, security, competitor from outside the area and competitor the same business.

Therefore, this indicates that the ABDA GS responded very good opportunities like working relationship with partners and customers, technology, economic conditions, available of raw materials, supplying raw materials, the involvement of the regional government and the social and cultural activities and merchants intermediary, and it can minimize the threat of company strategy effectively able to profit from the opportunities and minimize the negative influence from external threats such as the market share, climate change, security, political competitors outside the area, business competitors the same raw material prices.

The strategy ST, on the ABD GS is -0.35 namely using the strength of the company to increase, face, avoid or reduce the impact of external threats. The strategy are increase and maintain the quality of products 1) in the market share, 2) in the same business competitors outside or in areas, and 3) in security threats. Therefore the internal strength maintaining or improving the quality of and capital is very important to reduce the threat of market share, the same business competitors in the region or outside the region, security politics and the current climate. The ABDA GS, creates ease the products by consumers and the price is easy to reach 
by consumers also with the ministry of manpower that can improve customer satisfaction and loyalty.

Strategy SO, on the ABDA GS is -0.63 take advantage of internal company strength factor to profit from external opportunities factors namely through 1) increase and maintain product quality through maintain relationships with partners, 2) increase, maintain and utilize the product quality to maintain emotional ties with customers, 3) improve and maintain quality products using or increase the current technology, 4) maintain product quality by utilizing the involvement of local government of Aceh, 5) maintain product quality by utilizing the condition and social culture wisdom, 6) maintain of quality product and advantage of the cooperation with the merchant broker in the product marketing, 7) increase the capital to take advantage from the opportunities in cooperation with business partners and the local government of Aceh, and 8) increase capital business using the merchant broker.

Because of the ABDA GS improve the quality products using the appliance technology from upstream to downstream, working with consumers in discussing the product prices are easy reach by consumers with their economic condition, the cooperation with related partners with access to the products so that the income of the ABDA GS increased, involving the local government to get training or expertise of the ministry for employees such as from the Education Department of Industry, cooperatives and microfinance unit Banda Aceh City, Animal Health Office and Animal Husbandry Aceh, Tourism and Culture of Aceh and other stakeholders. The capital can collaborate with suppliers as raw materials is still be there.

The strategy WT, on the ABDA GS is -1.19 , namely improve or minimize the factors internal weakness in the ABDA GS to survive or avoid the threat of external factor, namely through strategy 1) increase product promotion in face of market share through off/online promotions or soft/ hard tools, 2) increase product promotion in cooperation with the same business competitors inside and outside the region, 3) maintain exist product promotion in the face of security threats through cooperation with stakeholders, 4) improve service performance of company in face of market share through human resources capacity, 5) improve service performance of the company in the face of the same business competitors with inside and outside the region, and 6) improve performance service of the company face of security threats through emotional closeness with working partners and consumers. Therefore the ABDA GS can improve the factor of weakness which is owned by increasing the finance companies to avoid the threat from the same business competitors inside and outside area, and improve innovation product at least a new brands and performance service employees in order to survive when there is a dynamic result from politic and security can affect the price of raw meat, and minimize the impact the influence of climate change on the products that can reduce the risk of ABDA GS. If in strategy WT this really is in a dangerous position and the ABDA GS must strive to survive, merger, or radically downsize the business.

The strategy WO, on the ABDA GS is -1.47 , namely the ABDA GSS must increase, resolve or improve internal weakness factors and take advantage or take advantage of external opportunities factor, namely through a strategy they are: 1) increase product promotion by the system of cooperation with partners, 2) increase product promotion through emotional relationship consumers, 3) increase product promotion through technology today, 4) increase product promotion through cooperation with the local government of Aceh, 5) increase product promotion with using economic conditions today, 6) increase product promotion through social activities of the cultural, 7) increase product promotion through cooperation with merchants, 8) improve performance service of the company through the opportunity of cooperative relationship between business partners and customers, 9) improve the services company performance use of current technology, 10) increase The Ministry of the 
performance of the company through the program of local government of Aceh, 11) improving service performance of the company through the economic condition of the company currently, 12) improve the services company performance through social and cultural actors and 13) improving service performance of the company through the merchant mediator such as customer complaints, advice consumers and others in the products produced. ABDA GS can increase products durability and product innovation through technology, reduce business risk through the creation of a good relationship with business partners and customers, improve ABDA GS financial with increased promotion of product and service performance of employees is also still working with traders broker in the product marketing, perform related product innovation with social activities local community culture especially so easy to marketed products and improve the cooperation with the supplier such as beef so that the availability of raw meat always available.

This is relevant with Markides [8] that need to build cooperation with buyers, suppliers, the same business competitors and competitor outside the area, economic practitioners and others as market development efforts to enhance the profit business players ADSA., 2). Interestingly enough (U.S. value 3) consists of The Internal Factors namely manpower, power hold product, product promotion and the service of employees and external factors is the technology to supply raw materials, the involvement of the regional government and the social and cultural. This is in line with Kusdiani [4] that product quality identification needs to be done so that the quality of the ADS product guaranteed, and product promotion and employees ABDA-GS service have strong influence to development of the market, and 3). Quite Interesting (U.S. value 2) consists of The Internal Factors in the form of business risk and external factors namely social culture. Although in both ABDA-GS has weaknesses in the business risk but can be addressed in strength factor on The Internal Factors, and also on the external factors, namely social culture, both ABDA-GS has great opportunities in the market its products due to many social and cultural activities in the province of Aceh community associated with the consumption of meat in particular and also the national society in general.

This is relevant with the Government Regulation No.68 2002 about national food resilience that agro-industry (beef dendeng) is the raw material processing industry with commodities of cattle to produce a product that economic value, meet customer needs and the development of animal food resilience among others: (1) food that is available not only to meet the needs of calories but have the composition of nutrients in accordance with the requirements of the body metabolism and free from materials and or the organism pathogenic virus; (2) food should distribute from both the dimensions of space and time evenly; (3) in the socio-cultural in accordance with the desire and public perception; (4) food should be used properly to meet the nutrition that is needed for the growth of health and productivity. Local culture and institutional have important role in transforming the comparative advantages become competitive advantages which eventually can strengthen regional agribusiness product competitiveness.

Jamilah [9] also states that to increase their food availability fats then required increased the population of cattle aceh as raw materials and agro-industry (beef dendeng) each year and is required for the empowerment of local breeder, the use of technology in improving the infrastructure of the husbandry and increase awareness and assistance from local government.

Karim [10] stated that to increase the population of cattle Aceh, Aceh Government have set up a regional development program local Cow Aceh specified in Aceh Development Planning for 5 Districts in Aceh Province. As the Law No. 9 of 1995 that the development of agro-industry business scale and micro scale farming or small by the individual or group is the duty and responsibility of the local government in realizing the national economy nations. 
According to the Bereue Statistic Agency Banda Aceh City in 2011 that opportunity development of agro industry animal husbandry (dendeng business) cows aceh beneficial for the regional government that is since a crisis until 1998, agro industry farms in Aceh remains survive, and on 2010 is also able to accommodate employment most high 175 people, with investment value third sequence from other industries namely IDR. 1.134.000.000,production cost high IDR. 2.290.000.000,- and gross value added most high IDR. 1600.000.000,-.

\section{Conclusions}

In Aceh ABDA-GS, the Internal Factors that need to be done on the improvement, strengthening and maintaining is product quality and capital (power), and the promotion of our products and services (weakness), while external factors is needed to be done improving utilization of or cooperation with partners, consumers, technology, the involvement of local government of Aceh, economic conditions today, activities/ perpetrators social culture, and traders broker (chance) and markets, competitor inside and outside area also security.

\section{Acknowledgements}

Thank you I say to a lecturer at the University of Brawijaya and Kanjuruhan Malang, University of Almuslim, and the staff of the Animal Health and Animal Husbandry Aceh province on the porch of the superior Cattle Frequented Aceh and also the PT Beef Dendeng Aceh Gunung Seulawah that has been working in a participative manner in completing this research.

\section{References}

[1] Sugiyono, Metode Penelitian Bisnis, 2008. Bandung: Alfabeta, 2009.

[2] J. L. Dillon and J. B. Hardaker, Farm management research for small farmer development, vol. 41. Food \& Agriculture Org., 1980.

[3] S. Nasution, Metode Research Penelitian Ilmiah. Jakarta: Bumi Aksara, 2001.

[4] Y. Kusdiarni, "Product Quality Analysis of Beef Dendeng Brand Cakrodonya. Case Study on Blangrakal Meat Shop, Banda Aceh City," Institut Pertanian Bogor, 2002.

[5] M. Ismail and W. Syafitri, "Model Pengembangan Agroindustri Unggulan untuk Memperkuat Daya Saing Daerah,” J. TEMA, vol. 6, no. 1, pp. 26-50, 2005.

[6] T. Zhou, "An empirical examination of continuance intention of mobile payment services," Decis. Support Syst., vol. 54, no. 2, pp. 1085-1091, 2013.

[7] Y. Zheng, K. Zhao, and A. Stylianou, "The impacts of information quality and system quality on users' continuance intention in information-exchange virtual communities: An empirical investigation," Decis. Support Syst., vol. 56, pp. 513-524, 2013.

[8] C. Markides and C. D. Charitou, "Competing with dual business models: A contingency approach," Acad. Manag. Perspect., vol. 18, no. 3, pp. 22-36, 2004.

[9] Jamilah, "Analisis perilaku dan kinerja pasar serta alternatif kebijakan pengembangan sapi potong," Apl. Manaj., vol. 8, no. 4, 2010.

[10] A. Karim, "Enam Daerah Jadi Pusat Agroindustri," Tabloid Tabagun Aceh, 2013. 